\title{
Respon Pemberian Virgin Coconut Oil dan Olive Oil Terhadap Mikroanatomi Testis Tikus Putih Jantan (Rattus norvegicus)
}

\section{Response Microanatomy Testis Male Rats (Rattus norvegicus) to Provision of Virgin Coconut Oil and Olive Oil}

\author{
Sella Widya Astuti ${ }^{1}$, Enny Yusuf Wachidah Yuniwarti ${ }^{2}$, Muhammad Anwar Djaelani ${ }^{2}$ \\ ${ }^{1}$ Program Studi Biologi, Departemen Biologi, Fakultas Sains dan Matematika, Universitas Diponegoro \\ ${ }^{2}$ Departemen Biologi, Fakultas Sains dan Matematika, Universitas Diponegoro \\ Jl. Prof. Soedarto, SH Tembalang Semarang \\ *Email : sellawidyaastuti@gmail.com
}

Diterima 26 Juli 2016/Disetujui 17 Februari 2017

\begin{abstract}
ABSTRAK
Virgin Coconut Oil memiliki kandungan vitamin E dan polifenol yang mampu meningkatkan enzim-enzim antioksidan dan menurunkan kandungan peroksida, sedangkan olive oil berperan sebagai antioksidan karena adanya oleocanthal dan oleuropein yang serupa dengan vitamin E. Penelitian ini bertujuan untuk mengetahui manfaat VCO dan olive oil terhadap spermatogenesis. Penelitian ini menggunakan 25 ekor tikus jantan yang terdiri atas 5 perlakuan dan 5 ulangan. Perlakuan yang digunakan yaitu P0: kontrol, P1: pakan dengan penambahan VCO $5 \mathrm{ml} / \mathrm{kg}$ pakan, P2: pakan dengan penambahan VCO $10 \mathrm{ml} / \mathrm{kg}$ pakan, P3: pakan dengan penambahan olive oil $5 \mathrm{ml} / \mathrm{kg}$ pakan, dan P4: pakan dengan penambahan olive oil $10 \mathrm{ml} / \mathrm{kg}$ pakan. Penelitian ini menggunakan Rancangan Acak Lengkap (RAL). Variabel yang diamati adalah jumlah spermatogonia, jumlah spermatosit primer, dan bobot testis. Data yang diperoleh kemudian dianalisis dengan menggunakan uji ANOVA pada taraf signifikansi 5\% dan uji lanjut Duncan. Hasil analisis data menunjukkan tidak terdapat perbedaan yang nyata pada pemberian VCO dan olive oil terhadap jumlah spermatogonia dan bobot testis, serta berbeda nyata terhadap jumlah spermatosit primer. Simpulan dari penelitian ini VCO dan olive oil dapat meningkatkan jumlah spermatosit primer pada tubulus seminiferus.
\end{abstract}

Kata kunci: Virgin Coconut Oil, olive oil, testis

\section{ABSTRACT}

Virgin Coconut Oil contains vitamin E and polyphenols that can increased antioxidant enzymes and reduce peroxides, however olive oil serves as antioxidant because oleocanthal and oleuropein were similar to vitamin E. This research aimed to study the benefit of VCO and olive oil for spermatogenesis. This research used 25 male rats which consists of 5 treatments and 5 replicates. The main experiment used P0: control, P1: food added with $5 \mathrm{ml} / \mathrm{kg}$ of VCO, P2: food added with $10 \mathrm{ml} / \mathrm{kg}$ of $\mathrm{VCO}, \mathrm{P} 3$ : food added with $5 \mathrm{ml} / \mathrm{kg}$ of olive oil, and P4: food added with $10 \mathrm{ml} / \mathrm{kg}$ olive oil. This research used CRD method (complete randomized design). The observed variables was the number of spermatogonia, primary spermatocytes, and testes weight, which at last the observation data would be experimented with ANOVA method on $5 \%$ significance and also further experimented with Duncan method. The analysis result showed that there was not significant between giving VCO and olive oil to spermatogonia and testes weight. The analysis data also showed that was VCO and olive oil affected the number of primary spermatocytes. The resume of this research was to study that both of VCO and olive oil can increased the number of primary spermatocytes on tubulus seminiferus.

Keywords: Virgin coconut Oil, olive oil, testes

\section{PENDAHULUAN}

Infertilitas merupakan masalah yang dialami pria dan wanita diseluruh dunia. Kasus infertilitas baik pria maupun wanita di negara-negara maju seperti Amerika dan Jepang ditemukan sekitar 80\% dari 400 juta pasangan. Para ahli memastikan angka 
infertil meningkat mencapai 15\%-20\% dari sekitar 50 juta pasangan di Indonesia (Wahyuni, 2012). Faktor infertilitas pria memegang peranan $50 \%$ dari keseluruhan kasus, antara lain disebabkan karena proses spermatogenesis kurang optimal (Agarwal and Prabakaran, 2005).

Spermatogenesis adalah proses terbentuknya spermatozoa dari spermatogonium, melalui proses perkembangan yang kompleks dan teratur. Spermatogenesis terjadi di dalam tubulus seminiferus testis (Widotama, 2008). Testis sangat rentan terhadap proses oksidasi oleh radikal bebas. Membran sel spermatogonia mengandung sejumlah besar asam lemak tak jenuh rantai ganda. Radikal bebas yang terbentuk jika bertemu dengan asam lemak tak jenuh ganda dalam membran sel, akan terjadi reaksi peroksidasi lipid (Sukmaningsih dkk., 2011). Peroksidasi lipid pada membran sel spermatogenik menghasilkan senyawa malondialdehyde (MDA) (Permatasari dkk., 2011).

Hewan tingkat tinggi yang hidup secara aerobik akan menghasilkan radikal bebas sebagai produk samping dari metabolisme tubuh, terutama yang berasal dari fosforilasi oksidatif dalam mitokondria (Widayati, 2012). Tubuh membutuhkan asupan antioksidan untuk menetralisir radikal bebas (Quratul'ainy, 2006). Antioksidan dapat berupa antioksidan endogen dan antioksidan eksogen. Antioksidan endogen yaitu antioksidan yang diproduksi di dalam tubuh seperti glutation peroksidase, superoksida dismutase, dan katalase. Antioksidan eksogen berasal dari makanan, seperti vitamin $\mathrm{E}$, vitamin $\mathrm{C}$, beta karoten, zinc, dan selenium (Silvani, 2015).

Virgin Coconut Oil (VCO) mengandung asam lemak jenuh yang tinggi sehingga menyebabkan VCO tahan terhadap proses ketengikan akibat oksidasi. VCO juga mengandung tokoferol. Tokoferol mengandung komponen aktif biologis sebagai aktivitas vitamin $\mathrm{E}$ yang berperan dalam menjaga kekebalan tubuh manusia (Alamsyah, 2005).

Penelitian yang dilakukan Jasda dkk. (2014), menunjukkan rerata jumlah spermatozoa pada tikus yang diberi diet lemak yang tinggi dan penambahan VCO sebesar $1 \mathrm{ml} ; 1,2 \mathrm{ml}$; dan $2 \mathrm{ml}$, mampu meningkatkan jumlah spermatozoa dibanding dengan tikus yang diberi diet lemak yang tinggi tanpa penambahan VCO. VCO diketahui juga dapat meningkatkan daya tahan tubuh hewan melalui peningkatan aktivitas fagositosis makrofag pada ayam yang diberi VCO $10 \mathrm{ml} / \mathrm{kg}$ pakan (Yuniwarti, 2013).

Sumber antioksidan juga terdapat pada olive oil. Olive oil mengandung senyawa seperti fenol, tokoferol, sterol, dan squalene yang berperan penting untuk kesehatan. Salah satu komponen penting olive oil adalah tokoferol yaitu vitamin E, yang terdiri atas tokoferol alfa, beta, gamma, dan delta. Olive oil sangat ideal sebagai antioksidan (Anggraeni, 2011).

Vitamin E diperlukan untuk menormalkan epitel pada tubulus seminiferus, dan memperlambat reaksi peroksidasi karena mampu menangkap radikal bebas dan memutus rantai proses peroksidasi lipid di dalam membran, sehingga terbentuk radikal vitamin E yang stabil dan tidak merusak (Astuti dkk., 2008). Berdasarkan latar belakang tesebut, maka perlu diteliti lebih lanjut mengenai respon pemberian Virgin Coconut Oil dan olive oil terhadap mikroanatomi testis tikus putih jantan (Rattus norvegicus).

\section{METODE PENELITIAN}

Penelitian ini dilaksanakan di Laboratorium Biologi Struktur dan Fungsi Hewan, Departemen Biologi, Fakultas Sains dan Matematika Universitas Diponegoro, pada bulan Januari sampai bulan Mei 2015. Hewan uji yang digunakan adalah tikus putih jantan strain wistar sebanyak 25 ekor. Kandang tikus yang digunakan berupa wadah plastik berbentuk kotak berukuran $25 \mathrm{~cm} \times 35 \mathrm{~cm}$. Kandang dibuat sebanyak 25 buah dan masing-masing kandang ditempatkan satu ekor tikus. Kandang dilengkapi dengan tempat makan dan minum tikus.

Penempatan kandang tikus dilakukan secara acak dengan cara membuat undian dari kertas. Tikus diaklimasi dalam kandang individu yang diberi sekam dan tempat makan selama 7 hari. Penelitian ini menggunakan 5 perlakuan, yang terdiri dari $\mathrm{P} 0$ : kontrol dengan pakan standart, P1: pakan dengan penambahan VCO $5 \mathrm{ml} / \mathrm{kg}$ pakan, P2: pakan dengan penambahan VCO $10 \mathrm{ml} / \mathrm{kg}$ pakan, P3: pakan dengan penambahan olive oil $5 \mathrm{ml} / \mathrm{kg}$ pakan, dan P4: pakan dengan penambahan olive oil $10 \mathrm{ml} / \mathrm{kg}$ pakan. Setiap perlakuan diulang sebanyak 5 kali ulangan. 
Perlakuan diberikan selama 4 minggu kemudian tikus dibedah untuk diambil organ testisnya, setelah sebelumnya dimatikan dengan pemberian anestesi. Testis ditimbang dengan timbangan analitik kemudian dibuat preparat histologis untuk diamati jumlah spermatogonia dan jumlah spermatosit primer.

Pembuatan preparat dengan menggunakan metode paraffin dengan pewarnaan Hematoxylin Eosin. Pengamatan jumlah spermatogonia dan spermatosit primer dilakukan dengan menggunakan fotomikrograf pada perbesaran 400x. Masing-masing preparat diambil 5 tubulus seminiferus yang memiliki bentuk sama dan kemudian dihitung jumlah spermatogonia dan jumlah spermatosit primer dengan menggunakan hand counter. Data berat testis, jumlah spermatogonia, dan jumlah spermatosit primer dianalisis dengan menggunakan uji ANOVA dan uji lanjut Duncan.

\section{HASIL DAN PEMBAHASAN}

Hasil analisis rata-rata dari jumlah spermatogonia, jumlah spermatosit primer, dan berat testis tikus dari penelitian dengan pemberian Virgin
Coconut Oil dan olive oil pada pakan disajikan pada Tabel 1.

Hasil analisis penambahan VCO dan olive oil pada pakan terhadap jumlah spermatogonia dengan Analysis of Variance (ANOVA) menunjukkan hasil yang tidak berbeda nyata $(\mathrm{P}>0.05)$. Hal ini menunjukkan bahwa VCO dan olive oil tidak mempengaruhi jumlah spermatogonia pada tubulus seminiferus tikus. Antioksidan pada VCO dan olive oil tidak berpengaruh terhadap jumlah spermatogonia diduga karena sel spermatogonia merupakan sel induk dimana proses spermatogenesis baru akan dimulai. Proses spermatogenesis dimulai dengan sel benih primitif, yaitu spermatogonia mengalami mitosis dan menghasilkan generasi sel-sel yang baru. Sel-sel ini dapat terus membelah sebagai sel induk, yang disebut spermatogonium tipe $\mathrm{A}$ atau dapat berdeferensiasi selama siklus mitosis yang progresif menjadi spermatogonium B. Spermatogonium tipe B berasal dari tipe A yang membelah dan meninggalkan kemampuannya untuk membelah secara mitosis, untuk kemudian menyelesaikan proses spermatogenesis (Akbar, 2010).

Tabel 1. Hasil analisis rata-rata jumlah spermatogonia, jumlah spermatosit primer, dan berat testis tikus.

\begin{tabular}{|c|c|c|c|c|c|}
\hline \multirow[t]{2}{*}{ Variabel } & \multicolumn{5}{|c|}{ Perlakuan } \\
\hline & P0 & P1 & $\mathrm{P} 2$ & P3 & P4 \\
\hline $\begin{array}{l}\text { Jumlah Spermatogonia } \\
\text { (sel) }\end{array}$ & $44,60^{\mathrm{a}} \pm 4,28$ & $50,20^{\mathrm{a}} \pm 2,95$ & $49,20^{\mathrm{a}} \pm 2,49$ & $47,00^{\mathrm{a}} \pm 2,92$ & $48,40^{\mathrm{a}} \pm 4,34$ \\
\hline $\begin{array}{l}\text { Jumlah Spermatosit } \\
\text { primer (sel) }\end{array}$ & $47,80^{\mathrm{b}} \pm 3,11$ & $54,60^{\mathrm{a}} \pm 2,30$ & $53,40^{\mathrm{a}} \pm 2,51$ & $51,60^{\mathrm{a}} \pm 3,13$ & $52,20^{\mathrm{a}} \pm 2,77$ \\
\hline Berat testis $(\mathrm{g})$ & $1,278^{\mathrm{a}} \pm 0,24$ & $1,336^{\mathrm{a}} \pm 0,07$ & $1,336^{\mathrm{a}} \pm 0,06$ & $1,294^{\mathrm{a}} \pm 0,06$ & $1,260^{\mathrm{a}} \pm 0,06$ \\
\hline
\end{tabular}

Keterangan : Angka yang ditunjukkan dengan superskrip yang sama pada baris yang sama menunjukkan perbedaan tidak nyata $(\mathrm{P}>0,05) . \mathrm{P0}$ : Pakan dengan perlakuan kontrol, $\mathrm{P} 1$ : Pakan dengan penambahan VCO 5 $\mathrm{ml} / \mathrm{kg}$ pakan, P2: Pakan dengan penambahan VCO $10 \mathrm{ml} / \mathrm{kg}$ pakan, P3: Pakan dengan penambahan olive oil $5 \mathrm{ml} / \mathrm{kg}$ pakan, dan P4: Pakan dengan penambahan olive oil $10 \mathrm{ml} / \mathrm{kg}$ pakan.

Hasil analisis penambahan VCO dan olive oil pada pakan terhadap jumlah spermatosit primer dengan Analysis of Variance (ANOVA) menunjukkan hasil yang berbeda nyata $(\mathrm{P}<0.05)$. Hasil uji lanjut dengan uji Duncan menunjukkan terdapat perbedaan nyata antara P0 dengan P1, P0 dengan $\mathrm{P} 2$, $\mathrm{P} 0$ dengan $\mathrm{P} 3$, dan $\mathrm{P} 0$ dengan $\mathrm{P} 4$, sedangkan P1 dengan $\mathrm{P} 2$, P3, dan $\mathrm{P} 4$ menunjukkan tidak berbeda nyata. Hal ini menunjukkan penambahan VCO dan olive oil pada pakan dapat meningkatkan jumlah spermatosit primer pada tubulus seminiferus. Peningkatan jumlah spermatosit primer tersebut diduga karena VCO mengandung asam laurat yang mampu menjadi sumber energi. Energi ini digunakan untuk meningkatkan metabolisme, sehingga dapat membantu 
berlangsungnya proses spermatogenesis (Jasda dkk., 2011). Sifat antioksidan yang terdapat pada VCO mampu untuk menurunkan stres oksidatif dan mencegah kerusakan jaringan pada testis serta melindungi jalur metabolisme testosteron terhadap peroksidasi (Dosumo et al., 2010).

Testosteron dihasilkan oleh sel interstitial leydig jika testis dirangsang LH dari kelenjar hipofisis dan jumlah testosteron yang disekresi kirakira sebanding dengan jumlah LH yang tersedia. Perubahan spermatogonia menjadi spermatosit dalam tubulus seminiferus dirangsang oleh FSH dari kelenjar hipofisis anterior. LH dan FSH disekresi oleh kelenjar hipofisis anterior akibat aktivitas saraf pada hipotalamus (Nandari, 2006).

Penelitian Yuniwarti (2015) menyebutkan bahwa kandungan vitamin E dan polifenol pada VCO mampu meningkatkan enzim-enzim antioksidan dan menurunkan kandungan peroksida, sedangkan olive oil berperan sebagai antioksidan karena adanya oleocanthal dan oleuropein yang serupa dengan vitamin E. Olive oil juga mengandung komponen fenol yang mempunyai efek positif terhadap kerusakan oksidatif. Senyawa polifenol meliputi flavonol, isoflavon, flavanon, antosianidin, katekin, dan biflavan. Polifenol bersifat sebagai antioksidan karena kemampuannya melawan pembentukan radikal bebas dalam tubuh (Putri dkk., 2014).

Jasda dkk. (2011) dalam penelitiannya menyebutkan VCO memiliki kandungan polifenol dan asam lemak dengan nilai tertinggi adalah asam laurat. Polifenol memiliki efek sebagai antioksidan dan prooksidan. Kandungan polifenol pada VCO, jika diberikan pada dosis tinggi dapat meningkatkan stress oksidatif karena tingginya antioksidan bersifat prooksidan sehingga dapat menyebabkan kerusakan membran karena lipid peroksidasi.

Peningkatan jumlah spermatosit primer setelah pemberian olive oil diduga karena olive oil memiliki peran penting dalam perbaikan kerusakan testis dengan mengurangi stres oksidatif dan melindungi kerusakan organ reproduksi selama toksisitas (AlAni, 2013). Vitamin E mampu mempengaruhi kualitas spermatozoa. Vitamin E merupakan agen pendorong atau pemacu fertilitas, yaitu untuk menormalkan epitel pada tubulus seminiferus. Degenerasi epitel tubulus seminiferus akibat defisiensi vitamin E pada tikus jantan menyebabkan penghambatan spermatogenesis, menghentikan produksi sperma, dan degenerasi sel benih (Astuti dkk., 2008).

Antioksidan mampu meningkatkan produksi testosteron, hormon penting yang terlibat dalam produksi dan pematangan spermatozoa di tubulus seminiferus dari testis. Hal ini mampu menghambat kerusakan pada membran sel akibat radikal bebas, sehingga ikatan antara hormon yang berperan dalam proses spermatogenesis dengan reseptor hormon tidak terganggu dan proses spermatogenesis lebih optimal (Umar dkk., 2015).

Hasil analisis penambahan VCO dan olive oil pada pakan terhadap berat testis dengan Analysis of Variance (ANOVA) menunjukkan hasil yang tidak berbeda nyata $(\mathrm{P}>0.05)$. Hal ini menunjukkan bahwa VCO dan olive oil tidak mempengaruhi berat testis tikus. Berat testis ditentukan oleh perkembangan epitelium seminiferi, karena tubulus seminiferus menempati sebagian besar volume testis. Jaringan interstisial menempati $6 \%$ dari volume testikuler dan sel leydig $2 \%$, sehingga jaringan interstisial dan sel leydig juga menentukan berat testis (Iryani, 2003).

Tubulus seminiferus merupakan bagian utama dari massa testis yang merupakan tempat berlangsungnya spermatogenesis. Sel-sel endokrin yang mengeluarkan testosteron yaitu sel leydig terletak dijaringan ikat antara tubulus-tubulus seminiferus. Sel leydig mengandung enzim-enzim dengan konsentrasi tinggi yang diperlukan untuk sintesis testosteron. Testosteron masuk ke lumen tubulus seminiferus setelah disekresikan untuk proses spermatogenesis (Wahyuni, 2012). Variabel berat organ merupakan indikator yang baik untuk menunjukkan aktivitas pertumbuhan sel dan aktivitas sekresi endokrin. Testis merupakan tempat pembentukan spermatozoa dari sel-sel germinativum primitif dan terdapat sel-sel leydig yang mensekresikan testosteron ke dalam darah (Nugraheni dkk., 2003).

\section{KESIMPULAN}

Hasil penelitian menunjukkan bahwa penambahan VCO dan olive oil pada tikus puth jantan (Rattus norvegicus) mampu meningkatkan jumlah spermatosit primer dalam tubulus seminiferus, sehingga dapat disimpulkan pemberian 
VCO dan olive oil mampu menginduksi proses pembelahan spermatogonia.

\section{DAFTAR PUSTAKA}

Agarwal, A. and S. A. Prabakaran. 2005. Oxidative Stress and Antioxidants in Male Infertility: a Difficult Balance. Iranian Journal of Reproductive Medicine. Vol. 3 (1) : 1-8.

Akbar, B. 2010. Tumbuhan dengan Kandungan Senyawa Aktif yang Berpotensi Sebagai Bahan Antifertilitas. Penerbit Adabia Press, Jakarta.

Alamsyah, A.N. 2005. Virgin Coconut Oil Minyak Penakluk Aneka Penyakit. Penerbit Agro Media Pustaka, Jakarta.

Al-Ani, N.K.H. 2013. Protective Influence of Olive Oil on Reproductive Parameters in Male Rat Treated with Cadmium. Global Journal of BioScience and Biotechnology (G.J.B.B). Vol.2 (4): 500-505.

Anggraeni, D. 2011. Manfaat Minyak Zaitun (Olive Oil) terhadap Kadar Low Density Lipoprotein (LDL) dalam Darah Tikus Wistar Jantan yang Diberi Diet Hiperlipidemia. Skripsi. Fakultas Kedokteran Gigi Universitas Jember, Jember.

Astuti S., D. Muchtadi., M. Astawan., B. Purwantara., dan T. Wresdiyati. 2008. Pengaruh Pemberian Tepung Kedelai Kaya Isoflavon, Seng $(\mathrm{Zn})$ dan Vitamin E terhadap Kadar Hormon Testosteron Serum dan Jumlah Sel Spermatogenik pada Tubuli Seminiferi Testis Tikus Jantan. JITV. Vol. 13 (4): 288293.

Dosumo, O.O., F.I.O. Duru, A.A. Osinubi, A.A. Oremosu, and C.C. Noronha. 2010. Influence of Virgin Coconut Oil (VCNO) on Oxidative Stress, Serum Testosterone and Gonadotropic Hormones (FSH, LH) in Chronic Ethanol Ingestion. Agriculture and Biology Journal of North America. Vol.1 (6): 1126-1132.

Iryani, D. 2003. Kadar Testosteron Darah dan Gambaran Histologis Sel-Sel Leydig Tikus Putih (Rattus norvegicus) Jantan Dewasa Setelah Pemberian Monosodium Glutamat Peroral. Majalah Kedokteran Andalas. Vol.27 (2): 50-59.
Jasda, A., Winarto, dan T.N. Kristina. 2014. Pemberian Virgin Coconut Oil untuk Meningkatkan Jumlah dan Motilitas Spermatozoa: Studi pada Tikus Wistar dengan Diet Tinggi Lemak. Jurnal Penel Gizi Makan. Vol. 37 (2): 161-167.

Nandari, R. 2006. Pengaruh Pemberian Ekstrak Belimbing Wuluh (Averrhoa bilimbi L.) Terhadap Kadar Testosteron Bebas dan Libido Tikus Jantan Galur Wistar. Tesis. Program Pascasarjana Universitas Diponegoro, Semarang.

Nugraheni, T., O.P. Astirin, dan T. Widiyani. 2003. Pengaruh Vitamin $\mathrm{C}$ terhadap Perbaikan Spermatogenesis dan Kualitas Spermatozoa Mencit (Mus musculus L.) Setelah Pemberian Ekstrak Tembakau (Nicotiana tabacum L.). Jurnal Biofarmasi. Vol.1 (1): 13-19.

Permatasari, H.K., N. Permatasari, dan Subandi. 2011. Pengaruh Ekstrak Jintan Hitam terhadap MDA dan Sel Spermatogonium Tikus yang Dipapar Asap Rokok Kretek Subakut. Jurnal Kedokteran Brawijaya. Vol.26 (3): 161-165.

Putri, B.E., H. Soetjipto, dan S. Hartini. 2014. Kadar Polifenol dan Efek Antioksidan Ekstrak Etanol Buah Sosis (Kigelia Africana (Linn.) Benth.) Serta Aplikasinya dalam Sabun Transparan. Seminar Nasional Kimia dan Pendidikan Kimia VI. 326-331.

Quratul'ainy, S. 2006. Pengaruh Pemberian Vitamin E terhadap Jumlah SpermatozoaMencit Jantan Strain Balb/C yang Dipaparkan Asap Rokok. Skripsi. Fakultas Kedokteran Universitas Diponogoro, Semarang.

Silvani, L. 2015. Melatonin Menghambat Penurunan Aktivitas Superoksida Dismutase Tikus Putih Jantan (Rattus norvegicus) Galur Wistar dengan Aktivitas Fisik Berlebih. Tesis. Program Studi Ilmu Biomedik Pasca Sarjana Universitas Udayana, Denpasar.

Sukmaningsih, A.A.Sg.A., I.G.A.M. Ermayanti., N.I. Wiratmini., dan N.W. Sudatri. 2011. Gangguan Spermatogenesis Setelah Pemberian Monosodium Glutamat pada Mencit (Mus musculus L.). Jurnal Biologi.Vol. 15 (2) : 4952. 
Umar, S.H., E.D. Queljoe, dan L. Tendean. 2015. Pengaruh Pemberian Ekstrak Kulit Buah Manggis (Garcinia mangostana L.) Terhadap Kualitas Spermatozoa Wistar Jantan (Rattus norvegicus) yang Diberi Paparan Suhu Panas. Jurnal e-Biomedik (eBm). Vol. 3 (2) : 670-675.

Wahyuni, R.S. 2012. Pengaruh Isoflavon Kedelai Terhadap Kadar Hormon Testosteron Berat Testis Diameter Tubulus Seminiferus dan Spermatogenesis Tikus Putih Jantan (Rattus norvegicus). Tesis. Program Studi Ilmu Biomedik Universitas Andalas, Padang.

Widayati, E. 2012. Oxidasi Biologi, Radikal Bebas, dan Antioxidant. Artikel Ilmiah. Bagian Kimia-Biokimia FK Unissula, Semarang.

Widotama, I.G.B.G. 2008. Pengaruh Isolat Herba Vernonia cinerea terhadap Spermatogenesis Tikus Putih. Jurnal Kimia. Vol.2 (2). 117-124.

Yuniwarti, E.Y.W. 2013. Virgin Coconut Oil Meningkatkan Aktivitas Fagositosis Makrofag Ayam Pedaging Pascavaksinasi Flu Burung. Jurnal Veteriner. Vol.14 (2): 190-196. 